Gene patents
$\begin{aligned} & \text { German minister } \\ & \text { brings rules into line } \\ & \text { with rest of Europe } \\ & \mathrm{p} 664\end{aligned}$

\title{
German scientists left in the cold as Berlin rejects rescue plan
}

Alison Abbott and Ute Gitschel, Munich

At the time of German reunification in 1990, 1,500 hand-picked scientists from institutes run by the former east German Academy of Sciences were promised permanent jobs in universities. Initially, they were all supported by an interim programme, the Wissenschaftler Integrationsprogramm (WIP), and for a very small number this led to fulltime employment.

But the majority have not been so lucky, and now 200 such scientists in Berlin face unemployment because the city is backing out of an agreement to co-finance a followup rescue programme. The other five Länder (states) continue to support the programme. And at a meeting last week, the so-called WIPianers agreed to lobby parliamentarians in Berlin to vote against the Berlin government's move to drop out of the programme.

They are threatening firmer action if their requests are rejected. "Some said that they'd be prepared to take harsher protest measures if no solution is found," says Gottfried Seifert, a retired mathematician from the Technical University in Berlin and spokesman for the Berlin WIPianers.

The WIPianers were selected by Germany's science council, the Wissenschaftsrat, as high-calibre scientists who could help build up the research capacities of east German universities. But in practice few were integrated into the universities, as the programme coincided with drastic cuts to their faculties (see Nature 378, 656-657; 1995).

Berlin, a powerful centre for science before reunification, was host to one-third of all WIPianers. So far only 16 have permanent faculty positions in Berlin universities.

When the WIP programme ended in 1996, the priority shifted from integrating the WIPianers to keeping them employed on short-term grants. A special programme was set up to achieve this, co-financed by the federal and Ländergovernments.

This programme finishes at the end of the year, and remaining WIPianers had welcomed a move by the federal research ministry to set up another joint programme, worth around DM150 million (US\$70 mil-

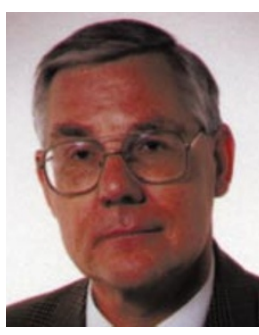

Sobotka: worried his team will be axed.

lion), to which they could apply.

Berlin, along with the five new Länder, signed up to the programme last year, committing itself to provide DM19 million in return for matching federal funds. But last month Berlin's science ministry said worsening financial circumstances meant that it could not provide matching funds.

Instead, the city has proposed that the money for co-financing any project under the programme should come from the universities, which are fully financed by the Länder government and where half of its 200 remaining WIPianers work. Non-university institutes, at which most of the remaining Berlin WIPianers work, would be legally barred from co-financing such projects as they are partly financed by the federal government.

But the universities, whose finances have almost halved in the past ten years (see Nature 380, 278; 1996), say they cannot afford to do this. The Humboldt University, for example, is already selling some of its buildings to repay extended credit from the ministry. And Berlin's Technical University says that its 2001 budget is not even enough to pay the salaries of its existing staff.

The other five Länder are all prepared to co-finance the programme, both to help the WIPianers but also for more pragmatic reasons. In the state of Brandenburg, for example, 115 WIPianers are working in universities and research institutes on money from the special university programme.

Friedrich Buttler, state secretary for Brandenburg's research ministry, says the scientists bring in around the same amount of money in research grants as the programme costs to run. "They are running 88 different research projects, involving 230 scientists: this is a very good return on investment," he says. Buttler is enthusiastic about the successor programme.

The WIPianers point out that, in contrast,

\section{Roslin backs off pig organ work}

\section{Declan Butler}

The Roslin Institute in Edinburgh - where Dolly the sheep was cloned - has been working to create transgenic pigs as a source of organs for transplant to humans. But the future of such efforts appeared in doubt this week, following comments by researcher Ian Wilmut that Geron Bio-Med intended to cut back on the research.

Wilmut said that the California-based company - which was created by the purchase of the Roslin Institute's commercial arm Roslin Bio-Med by the US biotech company Geron (see Nature 399, 92; 1999) - was concerned about the risks that xenotransplantation might create viral diseases in humans.

But Grahame Bulfield, director of the Roslin, told Nature on Monday that Wilmut

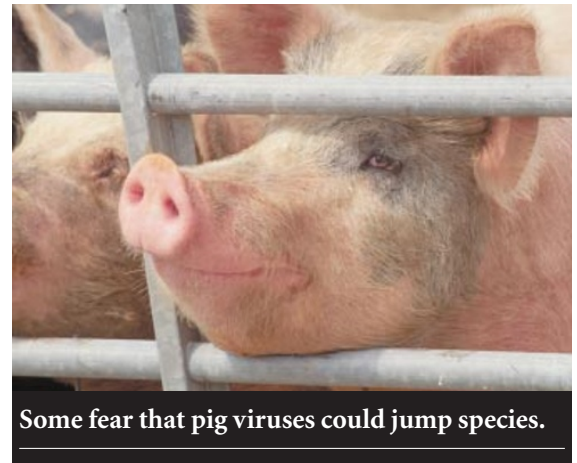

was speaking in a personal capacity. In comments later confirmed by Geron BioMed he added that if the company were to abandon xenotransplantation work, it would be purely on the grounds of refocusing research priorities, and not viral risk. 
Berlin stands to lose out on DM19 million in federal money if it refuses to cofinance the successor programme. "It is disgraceful," says Seifert, adding that during the three years of the special university programme, Berlin WIPianers won DM20 million in grant money.

The programme cost Berlin DM25 million, which was matched by federal funds. "Every mark paid by the city was converted to nearly three marks for research in Berlin," Seifert says.

But the average age of the remaining WIPianers is increasing and many fear that the excuse of impending retirement will be used to deal with the problem. Joachim Sobotka, a 62-year-old agricultural ecologist, says that if he is forced to retire early because his funds are discontinued, it will mean unemployment for the research team he has built up at Humboldt University, which has published 25 papers in the past few years.

Most Berlin WIPianers are unwilling to comment publicly on their plight, fearing that it could further jeopardize their employment prospects. But they plan to lobby Berlin's parliamentarians individually to ask them to vote against the science ministry's plans to withdraw from the new programme.

http://www.gew-berlin.de/wip/chronik1.htm

\section{German government takes a narrow view of gene patents}

\section{Quirin Schiermeier, Munich}

Germany's research minister Edelgard Bulmahn promised last week that new legislation on patents on genetic material would specify that they should be given a narrow interpretation.

The pledge came at a meeting attended by Bulmahn and the minister for legal affairs, Herta Däubler-Gmelin, as well as academics, industrialists and patent experts. The meeting discussed changes to Germany's patent laws that are to bring them in line with the European directive on the legal protection of biotechnology.

The commitment to the new legislation - which should have been approved by the end of last month - was welcomed by representatives from the biotechnology industry. "Harmonized European patent rules will give us the legal security we need," says Thomas von Rüden, chief scientific officer of the Munich-based company MorphoSys.

But there was also agreement at the meeting that patents issued should be interpreted in a "narrow way". This reflects concerns expressed last month by German scientists that broad gene patents could hinder the

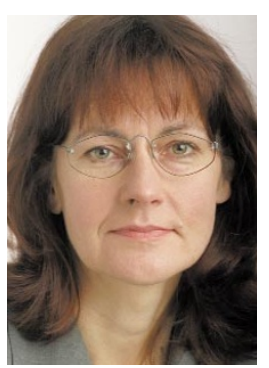

exploitation of newly discovered functions for DNA sequences (see Nature 406, 111; 2000).

Bulmahn said that the legal comments that would accompany the directive should encourage a 'researchBulmahn: wants laws friendly' interpreta-
friendly to research.

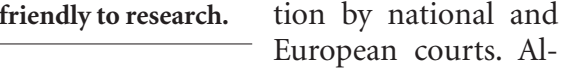
though not legally binding, these comments are aimed at guiding the interpretation of a law by the courts.

Some scientists oppose the idea that patents involving genetic information should get special treatment, believing that patents should be seen as incentives, rather than obstacles, to researchers.

But Detlev Ganten, scientific director of the Berlin-based Max Delbrück Center for Molecular Medicine, questions whether Bulmahn's concession goes far enough. "Gene patents should, on principle, be restricted to identified functions," he says.

\section{Deal on reprints could mean royalties for scientists}

\section{Rex Dalton, San Diego}

Many published scientists could be eligible for a share in a $\$ 7.25$ million settlement resulting from a federal lawsuit in Oakland, California. Approved by the US District Court late last month, the fund will compensate authors who have had reprints of published articles sold without their consent.

The class action lawsuit was launched two years ago when five authors sued UnCover, a document delivery firm based in Denver, Colorado, claiming that they had been cheated of royalty payments. Although the original plaintiffs were freelance writers and journalists, scientists are among the potential beneficiaries, as many of the articles distributed by UnCover were from scientific journals.

The compensation could be worth as much as $\$ 30,000$ per document delivery. But the actual amount will depend on the number of authors who successfully file claims, and may not be so high.

Any author who retained the rights to their work after initial publication is eligible to apply for compensation. Three-quarters of the settlement fund, less the estimated

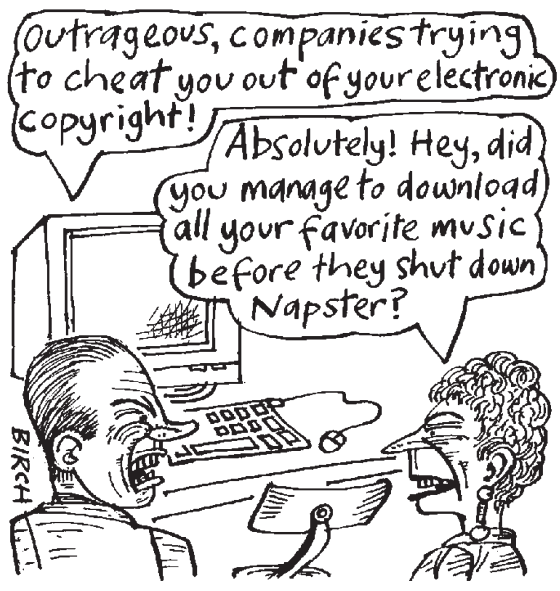

$\$ 3$ million in legal costs for the plaintiffs' attorneys, has been set aside for such claims. The remaining quarter will go to authors who did not register their US copyright, but retained the right after first publication.

"Selling individual articles electronically without authors' permission has been an industry-wide practice," says John Shuff, one of the authors' attorneys. He expects the case to have a significant impact on the burgeoning world of Internet publishing.
In some cases, UnCover had made arrangements to secure rights from publishers to distribute documents. But it had not always reached agreement with the authors. As part of the settlement, UnCover - now owned by the British firm Ingenta has agreed to seek the permission of authors and pay royalties in the future.

Robert Eisenbach, an attorney representing UnCover and Knight-Ridder, a previous owner of the company, said the settlement was reached to avoid future litigation costs.

Some observers believe that the agreement might hinder the distribution of scientific literature. Stevan Harnad, a professor of cognitive sciences at the University of Southampton in England, calls it "nothing but short-sighted nonsense". Others feel scientists are entitled to be paid for their work, just like any other author.

It is uncertain how many scientists are eligible for compensation because of the different arrangements between authors and publishers. Authors can check on the web whether UnCover distributed their articles. Claims must be filed by 27 October 2000 . http: //www.uncoversettlement.com 